\title{
Canários na Mina: \\ a Democracia, a Globalização \\ e o Populismo
}

\author{
Vasco Rato \\ Investigador no Instituto Português de Relações Internacionais da Universidade Nova de Lisboa
}

\begin{abstract}
Resumo
Este artigo avalia as principais causas do surgimento do populismo moderno nos Estados Unidos e nos países-membros da União Europeia. Argumenta-se que o populismo representa uma "forma de fazer política" assente, fundamentalmente, no anti-elitismo. Sugere-se, também, que o populismo deve ser entendido como uma expressão da "resistência cultural" à globalização. Mas o populismo pode corrigir disfuncionalidades gritantes verificadas nas sociedades pluralistas, evitando ruturas com a democracia
\end{abstract}

Palavras-chave: Populismo; Estado Unidos; Donald Trump; Globalização; Democracia; Crise Democrática.

\begin{abstract}
Canaries in the mine: democracy, globalization and populism

The article considers the main causes underlying the rise of populism in the United States and Europe. Populism is understood as "a way of doing politics", compatible with various ideologies. It is essentially marked by anti-elitism. Populism is also understood as a form of cultural resistance to globalization. The challenge, of course, is to find a democratic response to the populist moment. That response implies change that democratic elites are reluctant to accept.
\end{abstract}

Keywords: Populism; United States; Donald Trump; Globalization; Democracy; Democratic Crisis. 
Samuel Huntington, no seu célebre The Third Wave: Democratization in the Late Twentieth Century, observou que "vagas" de democratização invariavelmente provocam "vagas inversas" que resultam no colapso de democracias incapazes de se consolidarem ${ }^{1}$. O alerta de Huntington relativamente ao perigo da inversão democrática seria largamente ignorado porque, nos primeiros anos da década de 1990, se generalizou a convicção de que a democracia liberal vencera os múltiplos conflitos existenciais que enfrentara ao longo do "curto século $X X^{\prime 2}$. A novíssima ortodoxia mantinha que, em resultado da derrota militar dos fascismos europeus em 1945 e do subsequente desmoronamento do totalitarismo bolchevique, consumado em 1991 com a implosão da União Soviética, a democracia liberal - e a economia de mercado - constituía a única alternativa ideológica comportável com a natureza complexa e interdependente do "mundo moderno". Habilmente articulada por Francis Fukuyama, a tese do "fim da História" concedia, como não poderia deixar de ser, que inúmeros "eventos históricos" ocorreriam nas zonas de turbulência onde os sinuosos caminhos rumo à modernidade continuavam a ser obstinadamente trilhados ${ }^{3}$. Não obstante, a "História", entendida como o confronto entre meta-narrativas político-ideológicas, chegara ao seu termo com o esgotamento das alternativas que no passado haviam ameaçado as democracias liberais. Apesar do cuidado de Fukuyama em alertar para os dilemas e perigos inerentes ao "último homem" nietzschiano, a tese do "fim da história" rapidamente passou a espelhar o zeitgeist triunfalista do pós-Guerra Fria.

Invariavelmente, outros analistas da política internacional preconizaram a era pós-Guerra Fria de forma consideravelmente menos risonha. Contrastando com a visão traçada por Fukuyama, o influente jornalista Robert D. Kaplan, no livro The Coming Anarchy, apontava o emergir de um mundo distópico marcado pela escassez de recursos, incessantes vagas migratórias e a violência resultante do colapso de Estados frágeis ${ }^{4}$ Q Quanto aos países democráticos, teriam de absorver as ondas de

1 Samuel Huntington, The Third Wave: Democratization in the Late Twentieth Century. Norman: University of Oklahoma Press, 1991.

2 Ver, por exemplo, Stanley Kober, "Idealpolitik", Foreign Policy, no. 79, 1990, pp. 3-24. Sobre o "curto século XX", cf., Eric Hobsbawm, The Age of Extremes: The Short Twentieth Century, 19141991. Londres: Abacus, 1994.

3 Cf., Francis Fukuyama, The End of History and the Last Man. Nova Iorque: The Free Press, 1992. Para uma perspetiva crítica de Fukuyama, ver, Robert Kagan, The Return of History and the End of Dreams. Nova Iorque: Knopf, 2008.

4 Cf., Robert D. Kaplan, The Coming Anarchy: Shattering the Dreams of the Post Cold War. Nova Iorque: Random House, 2000. 
choque políticas e institucionais despoletadas por estes acontecimentos exógenos. Nem todos conheceriam o sucesso. Igualmente perturbante, Samuel Huntington, em "The Clash of Civilizations and the Remaking of World Order", identificava "fault lines" civilizacionais originárias de confrontos violentos em várias regiões do planeta ${ }^{5}$. No tocante à democracia, Huntington previa a sua persistência no mundo Ocidental, ao mesmo tempo que não se coibia de manifestar dúvidas relativamente à aplicabilidade universal do modelo liberal.

Anos mais tarde, contemplando as mutações político-institucionais ocorridas nas sociedades democráticas, e deveras influenciado pelo percurso político de Viktor Orbán, Fareed Zakaria popularizaria o termo "democracia iliberal" para distinguir regimes que, apesar de conservarem alguns dos procedimentos formais da democracia, incluindo a realização de eleições, impunham constrangimentos apreciáveis ao pluralismo social e político ${ }^{6}$. Formalmente democráticos, regimes deste tipo eram paulatinamente transformados em autocracias por via da erosão de um conjunto de direitos e garantias e da concomitante restrição da autonomia das instituições, colocando-as sob a tutela de um poder executivo crescentemente centralizado e autoritário. Este assalto à democracia liberal era, por regra, conduzido por partidos e movimentos populistas que, na década de 1990, começaram a agregar apoios na Europa e noutras regiões do mundo 7 .

Hoje, 30 anos após o colapso do Muro de Berlim, as sociedades democráticas vêm-se confrontadas com uma revolução populista de consequências indecifráveis. Não será, portanto, hiperbólico concluir que, nos países ocidentais, se vive

5 Publicado em 1993, o artigo original pode ser consultado em: Samuel Huntington, "The Clash of Civilizations?", Foreign Affairs, vol. 72, no. 3, verão de 1993, pp. 22-49. Posteriormente, o argumento seria desenvolvido em: Samuel Huntington, The Clash of Civilizations and the Remaking of World Order. New York: Simon \& Schuster, 1996. Entre as muitas críticas à tese de Huntington, cf., Jonathan Fox, "Paradigm Lost: Huntington's Unfulfilled Clash of Civilizations Prediction into the 21st Century", International Politics, vol. 42, no. 4, dezembro de 2005, pp. 428-457.

6 Cf., Fareed Zakaria, "The Rise of Illiberal Democracy", Foreign Affairs, novembro/ dezembro de 1997, vol. 76, no. 6, p. 22-43. Cf., também, Fareed Zakaria, The Future of Freedom: Illiberal Democracy at Home and Abroad. Nova Iorque: W. W. Norton \& Company, 2007. O conceito de democracia iliberal é frequentemente usado por Orbán. Por exemplo, num discurso proferido a 30 julho de 2014, o primeiro-ministro húngaro desenvolve o seu entendimento de democracia iliberal. Cf., "Prime Minister Viktor Orbán's Speech at the 25th Bálványos Summer Free University and Student Camp", disponível em http: / www.kormany.hu/ en/the-prime-minister / the-prime-minister-s-speeches / prime-minister-viktor-orban-s-speech-at-the-25th-balvanyossummer-free-university-and-student-camp.

7 Jack Hayward (ed.), Elitism, Populism, and European Politics. Oxford: Oxford University Press, 1996. 
uma "crise da democracia" de desfecho incerto ${ }^{8}$. A bom rigor, a inquietação provocada pelo alastrar do fenómeno populista atesta tanto o grau como a profundidade das incertezas quanto à sustentabilidade futura da democracia moderna. Os sinais de alerta são inequívocos. Partidos e movimentos de cariz populista reforçaram os seus apoios nas eleições para o Parlamento Europeu de 2014 e 2019, emergindo como os mais votados em França e no Reino Unido. Integram ou viabilizam coligações governamentais em vários Estados-membros da União Europeia, incluindo a Áustria, a Estónia, a Grécia e a Finlândia. Ao mesmo tempo, o Fidez húngaro, o Lei e Justiça (PiS) polaco e o Movimento Cinco Estrelas/Liga italiana comandam maiorias parlamentares que lhes garantem o pleno domínio do poder executivo e, segundo os seus adversários, lhes permite trilhar caminhos para o autoritarismo.

Balizado pelo referendo que aprovou o Brexit e pelo surpreendente triunfo de Donald Trump, o ano de 2016 afigura-se como uma espécie de Rubicão político que instalou dúvidas quanto à viabilidade do statu quo "liberal internacionalista" há décadas dominante nos dois lados do Atlântico9. Convém sublinhar que, por muito relevantes que possam ser, os sucessos populistas não se restringem às vitórias granjeadas nas urnas de voto. Mesmo os partidos populistas que até agora obtiveram resultados eleitorais modestos - como sejam a Alternative für Deutschland (AfD) e os Democratas Suecos (SD) - conseguem exercer vasta influência na medida em que balizam os termos do debate público em redor de questões fulcrais como a imigração, a abrangência do estado social, a política criminal ou os poderes e a legitimidade da União Europeia. Em resposta, na expetativa de virem a estancar futuras hemorragias eleitorais, os partidos centristas por vezes cooptam as propostas dos populistas. A título exemplificativo, o Partido Social Democrata dinamarquês, situado no mainstream do centro-esquerda europeu, mas pressionado nas urnas pelos populistas do Partido Popular Dinamarquês (DFP), efetuou uma alteração

8 Assistimos, periodicamente, a debates sobre a crise da democracia. Para alguns trabalhos recentes sobre a questão, influenciados pela crise de 2008 e o subsequente surgimento do populismo, cf., inter alia, Manuel Castells, Rupture: The Crisis of Liberal Democracy. Cambridge: Polity Press, 2019. Steven Levitsky, How Democracies Die. Nova Iorque: Crown Publishing, 2018. Jonah Goldberg, Suicide of the West: How the Rebirth of Tribalism, Populism, Nationalism, and Identity Politics is Destroying American Democracy. Crown Forum, 2018. E também, Patrick J. Deneen, Why Liberalism Failed. New Haven: Yale University Press, 2018.

9 Cf., Joseph S. Nye, Jr., "Will the Liberal Order Survive? The History of an Ideia”, Foreign Affairs, vol. 96, no. 1, janeiro/ fevereiro de 2017, pp. 10-16 e G. John Ikenberry, "The Plot against American Foreign Policy: Can the Liberal Order Survive", Foreign Affairs, vol. 96, no. 2, maio/ junho de 2017, pp. 2-9. 
significativa à sua política de imigração ${ }^{10}$. Também a recém-eleita líder da União Democrata Cristã (CDU) alemã, Annegret Kramp-Karrenbauer, se distanciou da política de "fronteiras abertas" de Angela Merkel, usualmente apontada como a principal responsável pelo surgimento da $\mathrm{AfD}^{11}$. Em resumo, no espaço euroamericano, assiste-se à consolidação do populismo e à paulatina erosão do consenso liberal centrista.

Este artigo avalia as principais causas do surgimento do populismo moderno nos Estados Unidos e nos países-membros da União Europeia ${ }^{12}$. Em conformidade com uma parte substancial da literatura académica sobre o tema, argumenta que o populismo se carateriza como uma "forma de fazer política" assente, fundamentalmente, no anti-elitismo ${ }^{13}$. Sugere, também, que o populismo deve ser entendido como uma expressão da "resistência cultural" à globalização, ou seja, o crescimento do populismo no espaço euro-atlântico é indissociável do contexto internacional criado pela globalização ${ }^{14}$. Há, porém, um aspeto em que este ensaio diverge da maioria dos

10 Sobre este processo, cf., Naomi O'Leary, “Danish left veering right on immigration", Politico, 9 de junho de 2018, consultado em https: / / www.politico.eu/article/danish-copenhagen-left-veers-right-on-immigration-policy-integration. Para uma análise mais detalhada, cf., Peter Nedergaard, "Back to its Roots: Why Do the Danish Social Democrats Want a More Restrictive Immigration Policy?" Friedrich Ebert Stiftung, Copenhagen 2018, disponível em https: / / library.fes.de/ pdf-files / bueros/ budapest/14498.pdf.

11 Cf., Madeline Chambers, "New leader of Germany's Christian Democrats signals shift away from Angela Merkel's liberal immigration policy", Independent, 9 de dezembro de 2018, disponível em https://www.independent.co.uk/news/world/europe/angela-merkel-migration-christian-democrats-annegret-kramp-karrenbauer-germany-a8675041.htm.

12 Existe uma vastíssima literatura académica sobre o populismo. Cf., inter alia, Cas Mudde e Cristobal Rovira Kaltwasser, Populism: A Very Short Introduction. Nova Iorque: Oxford University Press, 2017; Jan-Werner Müller, What is Populism? Philadelphia: University of Pennsylvania Press, 2016; Benjamin Moffitt, The Global Rise of Populism: Performance, Political Style, and Representation. Stanford: Stanford University Press, 2016; Ernesto Laclau, On Populist Reason, Londres: Verso, 2005; Francisco Panizza, Populism and the Mirror of Democracy. Londres: Verso, 2005; Cas Mudde, "The Populist Zeitgeist", Government and Opposition, vol. 39, no. 4, agosto de 2004, pp. 542-563, disponível em http:/ / onlinelibrary.wiley.com/doi/10.1111/j.14777053.2004.00135.x/ full; Yves Mény e Yves Surel, (eds.), Democracy and the Populist Challenge. Nova Iorque: Palgrave, 2002; Margaret Canovan, "'People', Politicians, and Populism", Government and Opposition, vol. 19, no. 3, julho de 1984, pp. 312-327; Margaret Canovan, Populism. Boston: Houghton Mifflin Harcourt, 1981.

13 Os estudos em português sobre o populismo são escassos. Cf., Nuno Severiano Teixeira, "Três Reflexões Inacabadas sobre Populismo e Democracia", Relações Internacionais, no. 59, setembro de 2018, pp. 75-83 e José Filipe Pinto, Populismo e Democracia: Dinâmicas Populistas na União Europeia. Lisboa: Edições Sílabo, 2017.

14 Para uma análise pioneira desta questão, cf., Benjamin R. Barber, Jihad vs. McWorld: Terrorism's Challenge to Democracy. Nova Iorque: Ballantine Books, 1996. 
escritos que retratam o fenómeno populista. Se é verdade que o populismo tendencialmente constitui uma ameaça existencial à democracia, é igualmente verdade que pode corrigir as disfuncionalidades mais gritantes das sociedades pluralistas ${ }^{15}$. Com efeito, o populismo, que passou a ser uma constante da paisagem política euroamericana, não deve, em qualquer circunstância, ser entendido como um instrumento de rutura com a democracia.

\section{Populistas São os Outros}

Componente ubíquo do léxico político contemporâneo, o termo "populista" tem, paradoxalmente, sido esvaziado de palpável conteúdo descritivo. A designação transformou-se num anátema, usualmente empregue de acordo com conveniências de natureza conjuntural para menorizar, desqualificar e denigrir rivais político-ideológicos. Populistas, muito simplesmente, tendem a ser os adversários de quem os carateriza dessa forma. Perante os sucessos populistas, cresce a tentação de rotular estes partidos como de "extrema-direita" ou "fascistas", assim ofuscando a verdadeira dimensão do fenómeno ${ }^{16}$. Na melhor das hipóteses, o adjetivo populista sinaliza comportamentos e posicionamentos que, em maior ou menor grau, destoam do "consenso alargado", ou seja, do "politicamente correto" hegemónico nas democracias europeias e americana. Dir-se-á, pois, que a denúncia do populismo funciona como um código semi-censório empregue para delimitar o âmbito aceitável, legítimo da discussão política. Porque o rótulo "populista" estigmatiza, o seu uso torna desnecessária qualquer ponderação das propostas apresentadas pelos "extremistas"17. Usado desta forma, o rótulo cria um escudo inibidor da mudança, assim contribuindo para a fossilização de sistemas políticos crescentemente fechados sobre si próprios. Este congelamento do sistema político, por sua vez, reforça e radicaliza o populismo, legitimando a denúncia das elites "afastadas da realidade" e indisponíveis para "ouvirem as pessoas comuns".

15 Dois trabalhos recentes que tratam este tema são: Yael Tamir, Why Nationalism? Princeton: Princeton University Press, 2019 e John B. Judis, The Nationalist Revival: Trade, Immigration, and the Revolt Against Globalization. Nova Iorque: Columbia Global Reports, 2018. Ver, também, a discussão em Cas Mudde e Cristóbal Rovira Kaltwasser, "Populism: corrective and threat to democracy", in Populism in Europe and the Americas: Threat or Corrective for Democracy? Cambridge: Cambridge University Press, 2012.

16 A título exemplificativo, cf., Enzo Traverso, The New Faces of Fascism: Populism and the Far Right. Londres: Verso, 2019.

17 Cf., Kenneth Roth, “The Dangerous Rise of Populism: Global Attacks on Human Rights Values", Human Rights Watch, consultado em https://www.hrw.org/world-report/2017/ country-chapters/ dangerous-rise-of-populism. 
A irrefutável vaga de contestação populista que alastrou ao longo das últimas décadas impõe um cuidadoso esforço de interpretação. Por muito impreciso que possa ser, o conceito "populismo", utilizado com a devida parcimónia e rigor, conserva uma certa utilidade analítica que não deve ser descartada. No momento atual, o "consenso geral" em torno do fenómeno assenta na premissa de que estes partidos são inerentemente antidemocráticos e, por conseguinte, a sua retórica e praxis são invariavelmente lesivas para as sociedades democráticas ${ }^{18}$. Como corolário lógico desta primeira premissa, conclui-se que os líderes populistas são putativos autocratas que apenas espreitam uma janela de oportunidade para estabelecerem "democracias iliberais". Em suma, o "consenso bien-pensant" sugere que, configurando uma ameaça existencial para os regimes democráticos, partidos "antiestablishment" carecem de legitimidade e, por conseguinte, devem ser objeto de marginalização política e mediática. Esta mesmíssima premissa informa, por exemplo, a postura de Emmanuel Macron relativamente aos populismos europeus, e ajuda a explicar a sua dificuldade em definir uma saída para o impasse francês simbolizado pela mobilização dos gilets jaunes $^{19}$.

Todavia, abordagens maniqueístas do populismo nada de útil acrescentam à reflexão sobre os desafios complexos enfrentados pela democracia contemporânea. A discussão sobre o fenómeno tornou-se largamente redutora porque, entre outras razões, sistematicamente recorre a exemplos e ensinamentos retirados do contexto latino-americano ${ }^{20}$. Uma vez que os populistas da América Latina, por regra, ameaçam a viabilidade da democracia pluralista, infere-se que, noutras regiões do mundo, movimentos de cariz populista são igualmente antidemocráticos. Trata-se de uma conclusão compreensível se se entender o peronismo, o "fujimorismo" e o "chavismo" como paradigmáticos do populismo; isto é, se forem vistos como expressões da essência do fenómeno. Mas há outros casos de populismo, incluindo o "bolsonarismo", que, claramente, não se enquadram neste tipo de leitura.

18 Ver, por exemplo, um interessante estudo sobre a Front National francesa: Mabel Berezin, Illiberal Politics in Neoliberal Times: Culture, Security and Populism in the New Europe. Cambridge: Cambridge University Press, 2009.

19 Cf., Julien Martin, “Gilets jaunes": la stratégie de Macron pour s'en sortir", L'Obs, 21 de fevereiro de 2019, disponível em https:/ / www.nouvelobs.com/politique/20190219.OBS0474/ giletsjaunes-la-strategie-de-macron-pour-s-en-sortir.html e XXXhttps://www.politico.eu/article/ yellow-jackets-protests-paris-police.

20 Há uma vasta bibliografia sobre o populismo latino-americano. Cf., inter alia, Robert R. Barr, A Resurgence of Populism in Latin America. Boulder: Lynne Rienner Publishers, 2017; Michael L. Conniff (ed.), Populism in Latin America: Second Edition. Tuscaloosa: The University of Alabama Press, 2012; e Sebastian Edwards. Left Behind: Latin America and the False Promise of Populism. Chicago: The University of Chicago Press, 2010. 
De qualquer forma, uma transposição direta, mecânica destas experiências para as sociedades europeias e americana ignora variáveis que, em grande medida, inviabilizam generalizações feitas a partir dos casos latino-americanos. Desde logo, as debilidades das instituições latino-americanas - e, em particular, do Estado - dificilmente permitem comparações com populismos que se manifestam em contextos de robustez institucional, como, aliás, se verifica na Europa e nos Estados Unidos. A observação é relevante na medida em que indica que o desafio populista à democracia pode ser neutralizado em países cujas instituições são suficientemente fortes para absorvê-lo, algo que, por regra, não acontece nos países latino-americanos.

A experiência empírica demonstra que enquanto alguns populismos preconizam soluções autocráticas que claramente subvertem os alicerces da democracia liberal, outros representam um impulso no sentido do aperfeiçoamento da democracia. Dito de forma diferente, o populismo contemporâneo, tal como o foi no passado, poderá ser um instrumento eficaz para ultrapassar alguma alienação política existente nas sociedades democráticas e para corrigir as suas disfuncionalidades. A "revolução jacksoniana" de 1828 e o populismo americano de finais do século XIX, liderado por William Jennings Bryan, exemplificam esse impulso no sentido da democratização ${ }^{21}$. Urge, pois, conceptualizar os populismos como uma espécie de "canários na mina" que, ao introduzirem na agenda política temas cuja discussão as elites normalmente visam evitar, alertam para sinais de descontentamento social e político que, não sendo enfrentados, podem, em último caso, provocar o desmoronamento das instituições democráticas. Convém, de igual modo, enfatizar que tal desfecho somente poderá ser consumado se as elites e as instituições demonstrarem abertura suficiente para interpretarem os sinais de mudança transmitidos pela sociedade através do populismo.

Há, é certo, uma inegável tensão na génese do populismo que deve ser salientada. Por um lado, os populistas encontram ressonância na Europa e nos Estados Unidos porque abordam anseios usualmente considerados inconvenientes pelo establishment político. Por outro lado, a lógica populista habitualmente rejeita o pluralismo social e político subjacente à democracia liberal, substituindo-o por visões holísticas, orgânicas da comunidade. Evidentemente, a discussão quanto à natureza do populismo e a sua relação com a democracia liberal necessariamente suscita inescapáveis interrogações. Por exemplo, pode o populismo - à semelhança do

21 Sobre o populismo americano, cf., inter alia, Chris Stirewalt, Every Man a King: A Short, Colorful History of American Populists. Nova Iorque: Hachette, 2018; Michael Kazin, The Populist Persuasion: An American History. Nova Iorque: Basic Books, 1995; Robert C. McMath, American Populism: A Social History, 1877-1898. Nova Iorque: Hill and Wang, 1992; Christopher Lasch, The True and Only Heaven: Progress and its Critics. Nova Iorque: W.W. Norton \& Company, 1991; e George McKenna, American Populism. Nova Iorque: Putnam, 1974. 
liberalismo, do fascismo ou do marxismo-leninismo - ser entendido como uma ideologia política autónoma? Há conteúdos ideológicos e programáticos específicos ao populismo? Podem os populismos ser avaliados nos mesmos termos em que são analisadas as principais correntes ideológicas dos nossos tempos?

Quanto à natureza do populismo, John B. Judis avança com uma resposta convincente quando observa que, no essencial, o fenómeno configura "uma lógica política - uma forma de pensar sobre a política" compatível com conteúdos ideológicos variados $^{22}$. Dito de forma diferente, populistas apresentam-se com roupagens "esquerdistas" ou "direitistas", não sendo o conteúdo ideológico do populismo o seu elemento diferenciador. A bom rigor, o traço comum à "forma de pensar sobre a política" populista reside na dicotomia povo-elite; isto é, na descrição da ação política como um conflito insanável entre "elites corruptas" e um "povo imaculado" fustigado e marginalizado pelo "sistema"23. A característica distintiva dos populismos é, portanto, o anti-elitismo. Claro que a descrição da atividade política como um conflito inexorável, e frequentemente apocalíptico, entre "nós" e "eles" não pode ser considerado um património exclusivo dos movimentos populistas. Carl Schmitt, entre outros, teorizou a política nestes mesmíssimos termos ${ }^{24}$. Lógica semelhante informa as teorias de "interest group politics" em sociedades democráticas desenvolvidas por, inter alia, Robert Dahl, David B. Truman, Charles E. Lindblom e David Easton $^{25}$. Justamente porque espelha a natureza conflitual da competição entre partidos políticos dentro de quadros institucionais democráticos, o binómio nós/eles encontra profundo eco junto da opinião pública, assim facilitando a disseminação da narrativa populista, frequentemente apresentada como "senso comum".

A distinção fundamental que permite separar os partidos democráticos dos populistas reside na aceitação da centralidade das instituições que expressam o pluralismo social. Ao aceitarem que a política visa a agregação, articulação e adjudicação de interesses num quadro institucional pluralista, os partidos democráticos

22 Cf., John B. Judis, "The Populist Explosion: How the Great Recession Transformed American and European Politics". Nova Iorque: Columbia Global Reports, 1916, p. 14. Um entendimento semelhante pode ser encontrado em Kirk A. Hawkins, "Is Chávez Populist? Measuring Populist Discourse in Comparative Perspective", Comparative Political Studies, vol. 42, no. 8, 2009, pp 1040-67.

23 Cf., Margaret Canovan, "Trust the People! Populism and the Two Faces of Democracy", Political Studies, vol. 47, no. 1, 1999, pp. 2-16.

24 A influência de Carl Schmitt permeia a análise do "momento populista" de Chantal Mouffe. Cf., Chantal Mouffe, For a Left Populism. Londres: Verso, 2018.

25 Ver, entre outros, Robert A. Dahl, Preface to Democratic Theory. Chicago: University of Chicago Press, 1956; David B. Truman, The Governmental Process. Nova Iorque: Knopf, 1951; David Braybrooke e Charles E. Lindblom, A Strategy of Decision. Nova Iorque. The Free Press, 1963; David Easton. A Systems Analysis of Political Life. Nova Iorque: Wiley, 1965. 
excluem monopólios quanto à legitimidade e à superioridade moral dos interesses sectoriais que encarnam. Em contraste com os partidos pluralistas, as forças populistas acrescentam uma dimensão moralista às categorias "nós" e "eles", manifesta no uso de termos como "a casta", "a oligarquia" e "os poderosos". Acrescenta-se que as narrativas populistas mantêm que as elites exercem o poder em benefício próprio, em detrimento das aspirações "genuínas" do povo. Eis a visão essencialista da sociedade e da ação política que, levada à sua conclusão lógica, fomenta o moralismo discursivo típico do populismo que transforma adversários políticos em inimigos destituídos de boa-fé e, por conseguinte, impossibilita o pluralismo.

Analisando os resultados eleitorais dos últimos anos, verifica-se, regra geral, que o nacional-populismo tem sido bem-sucedido porque tende a recriminar "elites" que promoverem os interesses de uma "parte", uma "secção" da nação e, como corolário, de "traírem" os "verdadeiros interesses do povo", entendido como a nação na sua totalidade. Leituras desta natureza tornam-se possíveis quando o conceito "povo" é operacionalizado de forma indiferenciada, ou seja, quando se nega a pluralidade de interesses (e aspirações) no seio da nação, atribuindo-lhe apenas um "interesse geral". Com efeito, a lógica axiomática subjacente ao "nós" e "eles" nega o pluralismo político e social, substituindo-o por uma visão holista, orgânica da nação. Confrontados com interesses que "destoam" das "genuínas aspirações do povo", os nacional-populistas explicam a "desunião" apontando para a existência de "interesses exteriores" à nação promovidos por outros Estados, por empresas transnacionais, pelos globalistas, pelos cosmopolitas ou, na ausência de melhor, por George Soros ${ }^{26}$. Assim se torna possível construir o discurso em volta dos "interesses genuínos" da nação.

Em sociedades massificadas, o populismo seduz porque, intuitivamente, não parece difícil identificar a elite política: são homens e mulheres que detêm cargos de topo nos partidos, nos parlamentos, nos executivos, no poder local e demais órgãos decisórios. A confluência entre a "elite política" e os detentores de cargos institucionais permite a identificação dos rostos da elite política, o que, por sua vez, gera a mobilização populista contra "os políticos". Esta mobilização visa desacreditar as instituições quando, por exemplo, os populistas insinuam que os membros do parlamento são "todos corruptos". Ao estabelecerem uma equivalência entre "políticos" e "corruptos", tornando-os sinónimos, retiram legitimidade às instituições para, de imediato, concluírem que os parlamentos são dispensáveis. Eis a dinâmica que, a não ser celeremente travada pela sociedade civil, ameaça os pilares centrais da democracia.

26 Sobre o caso húngaro, cf., Anne Corbett e Claire Gordo, "Academic Freedom in Europe: The Central European University Affair and the Wider Lessons", History of Education Quarterly, vol. 58, no. 3, agosto de 2018, pp. 467-474. 
Na perspetiva populista, a "elite política" não se resume aos detentores de cargos públicos, pois engloba sindicalistas, jornalistas, académicos e outros intervenientes que, indiretamente, se encontram ligados à atividade política. Por exemplo, órgãos de comunicação social de referência como o New York Times, o Washington Post e a CNN são vistos pelos "trumpistas" como pilares do establishment americano ao serviço do Partido Democrata. Fenómeno similar se verificou durante a campanha presidencial brasileira de 2018, quando a rede Globo e a Folha de São Paulo, alegadamente conotados com a agenda do Partido dos Trabalhadores (PT), foram sistematicamente atacados por Jair Bolsonaro. Se é verdade que a comunicação social crescentemente confunde opinião com informação isenta, é igualmente verdade que os populistas preferem uma comunicação direta, livre de mediação, com os eleitores. O resultado desta dinâmica traduz-se numa crescente fragmentação do discurso público e da criação de "tribos de opinião", usualmente constituídas através das redes sociais, que tornam o diálogo político entre adversários virtualmente impossível. Neste caldo cultural de polarização político-ideológica, o populismo, liberto das amarras do escrutínio introduzido pela mediação jornalística, consolida posições ${ }^{27}$. A ira populista também se dirige contra as "elites económicas" que, em contraste com a elite política, são mais difíceis de identificar com precisão. Visto que o poder destas elites é mais difuso, o populismo recorre a abstrações e condenações genéricas do "sistema". Reunido em movimentos como o Occupy Wall Street, os Indignados espanhóis ou em partidos como o Podemos, o populismo esquerdista denuncia os "grandes capitalistas", e, tal como os descamisados que engrossaram as fileiras do peronismo, alegam que "os $1 \%$ " detêm uma fatia desigual da riqueza, injustamente acumulada através da expropriação ilegítima dos restantes "99\% da população"28.

27 Cf., Gianpietro Mazzoleni, "Populism and the Media" in Daniele Albertazzi e Duncan McDonnell (eds.), Twenty-First Century Populism: The Spectre of Western European Democracy. Nova Iorque: Palgrave Macmillan, 2018, pp. 49-64.

28 Sobre os Indignados e o Occupy Wall Street ver, inter alia, Todd Gitlin, Occupy Nation: The Roots, The Spirit, and the Promise of occupy Wall Street. Nova Iorque: HaperCollins, 2012; Jenny Pickerill, "Why Does Occupy Matter?", Social Movement Studies: Journal of Social, Cultural and Political Protest, Vol. 11, no. 3-4, agosto de 2012, pp. 279-287; Ernesto Castañeda, "The Indignados of Spain: A Precedent to Occupy Wall Street", Social Movement Studies: Journal of Social, Cultural and Political Protest, Vol. 11, no. 3-4, agosto de 2012, pp. 309-319; Craig Calhoun, “Occupy Wall Street in perspective", British Journal of Sociology, vol. 64, no. 1, 2013, pp. 26-38; Sarah Van Gelder (ed.), This Changes Everything: Occupy Wall Street and the 99\% Movement. San Francisco: Berrett-Koehler Publishers, 2011. Sobre o Podemos, cf., Josh Booth e Patrick Baert, The Dark Side of Podemos? Carl Schmitt and Contemporary Progressive Populism. Nova Iorque: Routledge, 2018; José Fernández-Albertos, Los votantes de Podemos: Del partido de los indignados al partido de los excluídos. Madrid: Catarata, 2015; José Manuel Rodríguez Pardo, Podemos: ¿Comunismo, populismo o socialfascismo? Oviedo: Pentalfa Ediciones, 2016; e, John Müller (coord.), \#Podemos: Deconstruyendo a Pablo Iglesias. Zalla: Deusto, 2014. 
Visto do prisma populista, os 99\% constituem o "bom povo" virtuoso, explorado pelo egoísmo, avidez e malvadez dos $1 \%$. Colocada nestes termos, destituída das categorias tradicionais da análise de classe marxista, a discussão passa a ser essencialmente de teor moralista, limitando-se a expressar indignação com o "sistema capitalista" vigente e as "injustiças" que aparentemente fomenta. A falácia do populismo torna-se óbvia quando se pretende ir para além da indignação e do moralismo, ou seja, quando se procura formular políticas públicas concretas. Nessas ocasiões, rapidamente se torna evidente que os $99 \%$ não são uma massa indiferenciada unida por interesses uniformes. São, na realidade, uma amálgama de interesses irreconciliáveis. Daí a tentação de substituir soluções democráticas e complexas por fórmulas autoritárias e simplistas. Eis o dilema do populismo no poder, e a fonte do seu inevitável fracasso político em democracia.

Como seria de esperar, a censura populista das elites económicas e políticas ganha maior consistência durante crises económico-financeiras ou quando irrompem casos notórios de corrupção. Nessas ocasiões, torna-se possível identificar os rostos concretos dos "ladrões", caracterização que se generaliza para descrever os "ricos", os "tubarões" e os "oligarcas". Convém enfatizar que a categoria "ricos" não engloba pequenos comerciantes, lojistas e aforradores, invariavelmente apontados como vítimas da corrupção dos "grandes". Daí a defesa feita pelos populistas do comércio tradicional contra os hipermercados, ou dos pequenos investidores "lesados" na aquisição de produtos financeiros por uma banca "destituída de escrúpulos". Como é sabido, a denúncia dos "grandes", dos "oligarcas" dos "ricos", nunca foi um monopólio dos populismos de esquerda, pois o populismo direitista partilha deste tipo de narrativas. A título exemplificativo, recorde-se que os interesses representados pelo "big business" foram amplamente condenados pelo Tea Party americano porque desvirtuam o "level playing field" indispensável ao bom funcionamento do mercado ${ }^{29}$. Segundo esta linha de raciocínio, as grandes empresas, por meio do lobby e das contribuições financeiras canalizadas para os cofres dos partidos e das campanhas eleitorais, beneficiam de um sistema político que corrompem no quotidiano. Esta "compra de influência" possibilita a adoção de legislação específica que permite ao "big business" salvaguardar os seus interesses paroquiais. Cientes do problema, democratas e republicanos frequentemente reprovam a interferência do "dinheiro" na política, e periodicamente anunciam reformas às regras do financiamento das campanhas eleitorais.

29 Cf., Julia A. Spiker, "Palin, Bachmann, Tea Party Rhetoric, and American Politics", International Journal of Humanities and Social Science, Vol. 2, No. 16, Special Issue, August 2012, pp. 1-12. Para uma análise ponderada do Tea Party, cf., Theda Skocpol e Vanessa Williamson, The Tea Party and the Remaking of Republican Conservatism. Oxford: Oxford University Press, 2012. 
Chegados a este ponto, convém sublinhar a diferença entre o populismo do Tea Party e o populismo do Occupy Wall Street e do Podemos ${ }^{30}$. Apesar de ambos recorrerem à linguagem antielitista e à denúncia da corrupção, os primeiros visam corrigir um problema concreto que, de forma mais ou menos intensa, é sentido pela opinião pública e por uma parte da própria classe política. Se é verdade que o anti-elitismo é a linguagem deste tipo de populismo, é igualmente verdade que, independentemente do radicalismo da retórica, a sua lógica é inegavelmente reformista, pois visa mudar um componente do "sistema" e não o "sistema" na sua totalidade. Estamos, por outras palavras, perante um tipo de populismo suscetível de ser gerido pelas instituições democráticas. Em contraste, os segundos advogam a destruição do "sistema", único desfecho compatível com a exigência de "justiça" para os $99 \%$ da população. Eis, portanto, um tipo de populismo incapaz de ser enquadrado pelas instituições democráticas.

Face aos anseios presentes nas sociedades modernas que sustentam o fenómeno populista, duas conclusões afiguram-se como inegáveis. Primeira, estes partidos encontram extraordinária ressonância junto das populações. Segunda, a resposta pífia dada pelo establishment democrático gera um feedback loop que contribui para reforçar a contestação populista. Talvez o mais generalizado destes anseios - a imigração, especialmente a de origem muçulmana - tem sido invocado com grande eficácia para mobilizar o apoio de faixas significativas do eleitorado. Mas a discussão provocada pelo fenómeno migratório não se reduz às problemáticas identitárias suscitadas a propósito da inserção de "culturas estrangeiras" no "tecido cultural nacional" ${ }^{\prime 31}$. Engloba um leque vasto de temas incluindo o stresse financeiro colocado nos serviços públicos, a crise demográfica europeia e as lealdades das comunidades islâmicas - frequentemente entendidas como "quinta coluna" do terrorismo jihadista. Pilar central da visão articulada pela direita populista, o discurso anti-imigração encontra-se, por norma, ausente das preocupações da esquerda populista, cuja tradição internacionalista atenua este tipo de discurso.

Necessariamente resumida e incompleta, esta discussão do populismo pretende salientar que nem todos os populismos constituem ameaças existenciais à democracia. Sugere também que a probabilidade de se assistir a sucessos populistas aumenta na medida em que os partidos democráticos se fecham perante os anseios corporizados e expressos pelo populismo. Se os partidos democráticos conseguirem

30 Cf., Ana Paula Balthazar Tostes, Lucca Viersa e Barros Silva, “Das praças para as urnas: movimentos dos Indignados e Occupy Wall Street", Mural Internacional, Vol. 6 No, 2, julho/dezembro de 2015, consultado em https: / / www.e-publicacoes.uerj.br/index.php/muralinternacion$\mathrm{al} /$ article/view / 23761/17732.

31 Para uma discussão sobre este tema, cf., Francis Fukuyama, Identity: The Demand for Dignity and the Politics of Resentment. Nova Iorque: Farrar, Straus and Giroux, 2018. 
absorver os receios das populações e canalizá-los para as instituições, o populismo será domado. Note-se, a título exemplificativo, que a nova líder da CDU alemã, Annegret Kramp Karrenbauer, optou por prosseguir este tipo de estratégia. Por outro lado, uma vez que as origens do populismo moderno não se reduzem a variáveis de política interna, tornam-se incompreensíveis na ausência de uma referência às mudanças ocorridas na cena internacional no pós-Guerra Fria. Com efeito, porque a globalização gerou um conjunto de consequências que contribuíram para o alastrar do populismo, este não pode ser analisado apenas como um fenómeno de política interna divorciado de fatores e dinâmicas internacionais.

\section{Globalização e “Resistência Cultural”}

As décadas que antecederam a crise financeira de 2008 testemunharam o desenrolar de um processo de globalização que, para além das suas vertentes comercial e financeira, incorporou a revolução digital que suporta a proliferação das redes de partilha de conhecimento ${ }^{32}$. Nos anos 90 do século passado, era virtualmente consensual a noção de que a globalização conduziria a uma maior proximidade entre sociedades e, por conseguinte, à cooperação entre Estados. Afirmava-se que as fronteiras físicas e imateriais inibidoras da compreensão transcultural necessária para fomentar a cooperação internacional seriam superadas pelo acesso generalizado aos meios de comunicação digital - com destaque particular para a internet. Mediado pelo conhecimento mútuo, o desejável encontro do "outro" era apontado como a precondição para estabelecer a cooperação duradoura enraizada nos valores liberais inerentes à globalização.

Bill Clinton, o político que mais entusiasticamente abraçou esta conceção da globalização, entendia-a como um processo gerador da prosperidade económica, da democracia política e da cooperação entre povos e Estados ${ }^{33}$. A globalização saldava-se

32 Alguns dos trabalhos mais relevantes sobre a problemática da globalização são: Strobe Talbott, The Great Experiment: The Story of Ancient Empires, Modern States, and the Quest for a Global Nation. Nova Iorque: Simon \& Schuster, 2008; Joseph R. Stiglitz, Making Globalization Work. Nova Iorque: W. W. Norton, 2006; John Ralston Saul, The Collapse of Globalization: And the Reinvention of the World. Toronto: Penguin Canada, 2006; Martin Wolf, Why Globalization Works. New Haven: Yale University Press, 2004; David Held e Anthony McGrew (eds.), The Global Transformations Reader: An Introduction to the Debate (second edition). Cambridge: Polity Press, 2003; Peter L. Berger e Samuel Huntington, Many Globalizations: Cultural Diversity in the Contemporary World. Nova Iorque: Oxford University Press, 2002; e Joseph E. Stiglitz, Globalization and its Discontents. Nova Iorque: W. W. Norton, 2002.

33 A título exemplificativo, cf., The White House, "Remarks by the President on Foreign Policy", Grand Hyatt Hotel, San Francisco, California, February 26, 1999, disponível em https: / www. mtholyoke.edu/acad/intrel/clintfps.htm. 
por resultados win-win porque, na formulação de Thomas Friedman, produzia um mundo mais integrado e "plano" 34 . A globalização era, simultaneamente, uma consequência da modernização socioeconómica e uma espécie de motor dessa mesma modernização. À medida que as sociedades faziam a sua transição para a modernidade, emergiam "classes médias" novas que passariam a exigir participar na vida política, assim obrigando regimes autocráticos a criarem instituições pluralistas a fim de absorverem novas reivindicações sociais. A abordagem recuperava a lógica do "desenvolvimento" típica das "teorias de modernização" dominantes nas ciências sociais a partir dos anos 50 e 60, que antecipavam um mundo mais democrático e, como corolário, um sistema internacional mais pacífico ${ }^{35}$.

Independentemente das divergências que os separavam no tocante a um leque vasto de assuntos de política interna e externa, Bill Clinton, George W. Bush e Barack Obama partilharam o essencial desta visão globalista. De igual modo, convencidas que teriam entrado num mundo pós-moderno que lhes permitia escapar à logica hobbesiana do sistema internacional, as elites europeias subescreviam este mesmo entendimento benigno da política externa assente no internacionalismo liberal ${ }^{36}$. Na era pós-Guerra Fria, americanos e europeus encorajaram a globalização porque acreditavam que conduziria ao alargamento da democracia e da paz. Sendo assim, não surpreende que o establishment de política externa dos dois lados do Atlântico aceitasse como verdadeira a tese da paz interdemocrática; isto é, a convicção kantiana de que as democracias, mesmo que mais bélicas em relação às autocracias, não se guerreiam ${ }^{37}$. Concluindo-se que a expansão da democracia gerava uma espécie de "comunidade de paz", alargou-se a Aliança Atlântica e a União Europeia para o leste europeu e procedeu-se à adesão da China à Organização Mundial de Comércio.

Acreditando que o aprofundamento das relações comerciais com a China conduziria à integração plena deste país na economia mundial, o que levaria Pequim

34 Cf., Thomas Friedman, The Lexus and the Olive Tree: Understanding Globalization. Nova Iorque: Farrar, Straus and Giroux, 1999 e Thomas Friedman, The World is Flat: A Brief History of the Twenty-first Century. Nova Iorque: Ferrar, Straus and Giroux, 2005.

35 A literatura científica versando a "teoria da modernização" é vastíssima. Cf., inter alia, Seymour Martin Lipset, "Some Social Requisites of Democracy", American Political Science Review, vol. 53, no. 1, março de 1959, pp. 69-105; Samuel P. Huntington, Political Order in Changing Societies. New Haven: Yale University Press, 1968; e Adam Przeworski e Fernando Limongi, "Modernization: Theories and Facts", World Politics, vol. 49, no.2, janeiro de 1997, pp. 155-183.

36 Sobre esta visão da União Europeia e o seu papel no sistema internacional, cf., Robert Cooper, The Breaking of Nations: Order and Chaos in the Twenty-First Century. Nova Iorque: Atlantic Monthly Press, 2003.

37 Ver, Seung-Whan Choi, "Beyond Kantian Liberalism: Peace through Globalization?", Conflict Management and Peace Science, vol. 27, no. 3, julho de 2010, pp. 272-295. 
a democratizar internamente e a adotar um comportamento internacional pautado pela cooperação, vários governos europeus e administrações americanas anuíram perante as práticas comerciais discriminatórias chinesas ${ }^{38}$. Convencidos que a emergência da China como grande potência ocorreria de forma pacífica, os decisores ocidentais naturalmente aceitavam sacrifícios no curto prazo a nível da política comercial porque se tratava de um preço aceitável para garantir a integração de Pequim na economia mundial e, não menos importante, de obter acesso ao apetecível mercado chinês. Nos Estados Unidos, este consenso quanto à política externa, resultante da leitura feita relativamente à bondade da globalização, perdurou até ser enterrado por Donald Trump ${ }^{39}$. No espaço europeu, as atitudes relativamente à China continuam a ser marcadas por ambiguidades e contradições, manifestas em assuntos como o fornecimento de tecnologia 5G pela Huawei e os moldes da participação de Estados europeus no Belt and Road.

As expetativas sobre a ordem internacional pós-Guerra Fria partilhadas por americanos e europeus saíram largamente goradas porque a globalização se transformou num sinónimo de ocidentalização ${ }^{40}$. Acentuando a uniformidade cultural associada à modernidade euro-americana, a globalização revelou possuir uma lógica de homogeneização cultural. Por conseguinte, a confluência estabelecida ente "globalização" e "ocidentalização" universalizou-se à medida que as regiões anteriormente excluídas da economia mundial - a China e os países ex-comunistas europeus - foram absorvidas pela lógica globalizante. Expostos à mundivisão ocidental, os destinatários dos "encontros transculturais" e da democratização acabariam por rejeitar, por vezes através do uso da violência extrema, os valores e as instituições tidas como veículos da hegemonia ocidental. Deste modo, a oposição local à globalização metamorfoseou-se numa "resistência cultural" à ocidentalização, protagonizada por movimentos determinados a recuperar a "identidade nacional" e a "grandeza" dos respetivos países. Por exemplo, com o intuito de reconstituir um "califado" largamente imaginado, mas apresentado como paradigmático da grandeza islâmica de outrora, a Al-Qaeda e o Estado Islâmico encarnaram a rejeição da

38 Cf., inter alia, Jonathan Holslag, The Silk Road Trap: How China's trade Ambitions Challenge Europe. Cambridge: Polity Press, 2019 e Stewart Peterson, China, Trade and Power: Why the West's Economic Engagement Has Failed. Londres: London Publishing Partnership, 2018.

39 Peter Navarro emergiu como o mais importante dos conselheiros económicos de Donald Trump, parcialmente porque advogou uma postura hardline no relacionamento comercial com a China. Ver, por exemplo, Peter Navarro, Death by China: Confronting the Dragon - A Global Call to Action. Upper Saddle River: Prentice Hall, 2011.

40 Cf., Amy Chua, World on Fire: How Exporting Free Market Democracy Breeds Ethnic Hatred and Global Instability. Nova Iorque: Doubleday, 2003. 
globalização através da resistência religioso-cultural armada" ${ }^{41}$ Mas a "resistência cultural" à globalização não se restringia a estas expressões sanguinárias, pois, e independentemente das suas especificidades, o "putinismo", o Bharatiya Janata Party (BJP) de Narendra Modi, o Adalet ve Kalkınma Partisi (AKP) de Erdoğan e o Partido Comunista Chinês de Xi Jinping adotaram estratégias de "resistência cultural" assentes em nacionalismos chauvinistas que preconizam o regresso à "grandeza nacional".

A resistência à globalização, porém, não se manifestou exclusivamente em sociedades periféricas, não-ocidentais, a braços com os efeitos identitários produzidos pela lógica globalizante. Nos Estados Unidos e na Europa, emergiu uma clivagem política interna quando a globalização passou a ser entendida como a principal causa da erosão do nível de vida das classes médias. Gerando pressões no sentido da liberalização dos mercados de trabalho e da flexibilização das leis laborais nacionais, a globalização passou a ser responsabilizada pelo aumento do desemprego, pela estagnação dos salários reais e pelo acentuar da insegurança socioeconómica das classes mais vulneráveis. Os críticos da globalização acrescentam que a flexibilização da regulamentação que acompanha a livre circulação de bens e serviços destrói sectores tradicionais da economia, incluindo pequenos negócios, incapazes de resistir à concorrência de grandes empresas que consolidam as suas fileiras de distribuição. Concebida nestes termos, a globalização representa uma ofensiva do "grande capital" contra as classes trabalhadoras e as classes médias, enfraquecendo-as por meio da deslocalização de investimentos e atividades produtivas para países que concedem às empresas condições mais vantajosas ${ }^{42}$. Dá-se, portanto, uma espiral de concorrência para o "fundo", um empobrecimento tão gradual quanto inexorável em resultado da diminuição das capacidades reivindicativas dos trabalhadores.

Quanto a esta matéria, a leitura feita pelos nacional-populistas não se distingue substancialmente do populismo de esquerda. Ambos concebem a globalização como a primeira causa do incremento da precaridade, do desemprego, da estagnação salarial e, de modo geral, da degradação do nível de vida nas sociedades ocidentais. Há, porém, uma diferença de interpretação que separa os populistas de direita e de esquerda. Para os primeiros, os males das sociedades ocidentais residem, sobretudo, na imigração, uma consequência inevitável da globalização e das políticas de "fronteiras abertas" que a caraterizam. Afirma-se que imigrantes aceitam salários baixos e, dessa forma, usurpam os empregos das populações nativas,

41 Cf., Vasco Rato, "Nos desertos de al-Zarqawi: da Al-Qaeda ao 'Estado Islâmico'”, Nação e Defesa, N. ${ }^{\circ}$ 143, 2016, pp. 10-42 e Vasco Rato, Compreender o 11 de Setembro. Lisboa: Edições Verbo, 2011.

42 Ver, por exemplo, Chris Harman, "Globalisation: A Critique of a New Orthodoxy", International Socialism, 73, Inverno de 1996, pp. 3-33. 
particularmente dos menos qualificados. Em paralelo, alega-se que os imigrantes "se aproveitam" dos programas proporcionados pelo Estado social, assim provocando um excesso de procura dos serviços públicos que resulta na sua deterioração e no aumento do fardo dos contribuintes. Constatando que os recursos do Estado social são escassos, os populistas concluem que devem ser canalizados apenas para os membros da comunidade nacional, reforçando, desta forma, a demarcação nós / /eles, entre os que integram a comunidade política e os dela excluídos ${ }^{43}$.

Para os populismos de direita, a imigração apresenta um adicional perigo de natureza existencial: a erosão das culturas que sustentam a identidade e a coesão do estado nacional moderno. Se é verdade que praticamente nenhum partido hoje invoca a bandeira da "superioridade da raça branca", é igualmente verdade que se assiste à generalização da retórica do exclusivismo cultural assente na premissa de que as diferenças culturais entre europeus e "os outros" constituem um fosso inultrapassável que impossibilita a integração de não-ocidentais nas sociedades europeias. Esta "resistência cultural" também se expressa, porventura de forma mais nítida, através da ideia de que o islamismo constitui uma ameaça à cristandade, o pilar estruturante da identidade ocidental. É, aliás, esta visão sobre as ameaças à "civilização ocidental" que une Vladimir Putin e vários partidos populistas europeus.

Esta resposta identitária à globalização permite aos populistas de direita mobilizar os "perdedores da globalização" mais eficazmente do que os populismos de esquerda porque, na formulação de Hanspeter Kriesi, os "receios sobre identidades nacionais" são mais importantes do que a defesa de direitos económicos ${ }^{44}$. Colocada nestes termos, a conclusão de Kriesi parece contraintuitiva na medida em que minimiza o fenómeno que Hans-Georg Betz descreve como a "proletarização" da base eleitoral da direita populista ${ }^{45}$. A bom rigor, as duas observações são complementares, porque a imigração é entendida pelos partidos populistas como a principal causa da deterioração do status das classes médias e da sua efetiva proletarização. Perante a profunda insegurança em volta do status, reclama-se a intervenção do Estado no sentido de impor políticas protecionistas, o encerramento das fronteiras e restrições ao uso por estrangeiros dos serviços do estado social. Face à centralidade

43 Cf., Willem de Koster, Peter Achterberg e Jeroen van der Waal, "The new right and the welfare state: The electoral relevance of welfare chauvinism and welfare populism in the Netherlands", International Political Science Review, vol. 34, no. 1, janeiro de 2013, pp. 3-20.

44 Cf., Hanspeter Kriesi, Edgar Grande, Romain Lachat, Martin Dolezal, Simon Bornschier e Timotheos Frey, West European Politics in the Age of Globalization. Cambridge: Cambridge University Press, 2008, p. 19 e Hanspeter Kriesi, "The Populist Challenge", West European Politics, vol. 37, no. 2, abril de 2014, pp. 361-378.

45 Cf., Hans-Georg Betz, Radical Right-Wing Populism in Western Europe. Nova Iorque: St. Martins Press, 1994, p. 166. 
da questão identitária e da recuperação da grandeza nacional, o Estado passa a ser concebido como a "solução" para a insegurança económica e como o último reduto contra qualquer mudança.

Pouco importa se a globalização tem sido responsável pelos danos colossais que os populistas lhe imputam. A verdade incontornável é que a narrativa antiglobalização se generalizou e, hoje, faixas significativas da opinião pública democrática aderem à mundivisão construída pelos populistas. Se é verdade que a oposição europeia à globalização, tal como a americana, congrega vozes de esquerda e de direita, é igualmente verdade que as premissas subjacentes tendem a ser substancialmente diferentes. À esquerda, de forma geral, entende-se a globalização como a expressão da hegemonia do capitalismo financeiro e do neoliberalismo, usualmente caraterizado como a ideologia do império americano e das elites nacionais a ele aliadas. Em contraste, a direita europeia considera a globalização como uma espécie de coveiro da prosperidade da classe média e uma ameaça aos traços distintivos das culturas nacionais e dos Estados que as encarnam. Ambos, se bem que por razões diferentes, afirmam que o avanço da globalização e do neoliberalismo conduziu à erosão do modelo social europeu e à precaridade socioeconómica.

\section{O Populismo Veio para Ficar}

São escassos os partidos do mainstream político-ideológico euroamericano que ainda abraçam a globalização com o vigor demonstrado nos anos anteriores à crise financeira de 2008. Será, porventura, nos Estados Unidos que esse ceticismo mais se acentuou. Como é sobejamente conhecido, ao longo da campanha presidencial de 2016, o tema da globalização provocou uma acentuada clivagem entre Donald Trump e Hillary Clinton. Rosto emblemático do establishment político americano, a antiga secretária de Estado montou uma defesa intransigente da globalização, da ordem liberal e das normas que a sustentam. Em contraste, Trump, abandonou as tradicionais linhas programáticas do Partido Republicano: o internacionalismo e o comércio livre. Por outras palavras, rompeu com o "globalismo" há décadas subscrito pelas elites republicanas e, em seu lugar, ofereceu um nacional-populismo abertamente hostil ao "globalismo" dominante no interior dos dois maiores partidos americanos ${ }^{46}$.

Recorde-se que Donald Trump não fora o primeiro político americano a expressar reservas relativamente à globalização. Apesar de minoritária, há décadas que uma corrente no seio do Partido Republicano se mostrara deveras cética quanto à

46 Cf., Vasco Rato, “Trump num Novo Mundo", Nação e Defesa, n. 147, 2017, pp. 160-190 e Tiago Moreira de Sá e Diana Soller, Donald Trump - O Método no Caos. Lisboa: Dom Quixote, 2018. 
bondade do globalismo. Articulando este ponto de vista durante as primárias presidenciais de 1992 e 1996, Pat Buchanan fora pioneiro na condução de "campanhas insurgentes" contra o statu quo e na defesa de propostas que seriam subsequentemente recuperadas por Trump: o nacionalismo assertivo, a limitação da imigração, as barreiras alfandegárias e a revogação do NAFTA ${ }^{47}$. Buchanan antecipara Trump noutro aspeto crucial: fora pioneiro do discurso em defesa do "homem comum", dos "deserdados" da globalização que, de modo depreciativo, Hillary Clinton veio mais tarde caraterizar como "os deploráveis"48. Igualmente importante, fora um dos primeiros políticos a alertar para os riscos inerentes ao surgimento da China como grande potência. Contudo, Buchanan não seria o único a tentar romper com o consenso internacionalista do seu partido. Ron Paul, congressista do Texas, durante as primárias de 2008 e 2012, também se insurge contra as intervenções militares americanas, advogando o isolacionismo na cena internacional e o regresso ao padrão-ouro.

Mas a contestação à globalização nunca verdadeiramente se circunscreveu às elites do Partido Republicano. Influenciados pelas reivindicações de poderosos sindicatos alarmados com a desindustrialização e outras consequências do comércio livre, destacados elementos do Partido Democrata expressaram profundas e numerosas reservas quanto à globalização promovida pela ala "clintoniana". A título exemplificativo, Tom Harkin, nas primárias de 1992, e John Edwards, em 2004 e 2008, protagonizaram candidaturas populistas em nome dos "working Americans" fustigados pelas políticas globalistas. Recorde-se que, em 2004, Edwards fora o candidato a vice-presidente no ticket Democrata encabeçado por John Kerry, um sinal inequívoco do desconforto sentido em largos sectores do partido. Mais tarde, nas primárias de 2016, a ala que apoiara Harkin e Edwards mobilizou-se em volta da candidatura de Bernie Sanders, cujas críticas ao comércio livre obrigaram Hillary Clinton a esfriar o entusiasmo pela globalização que insistentemente expressara ao longo de um percurso político de duas décadas.

47 As ideias de Buchanan são desenvolvidas em vários livros, entre os quais: Pat Buchanan, The Great Betrayal: How American Sovereignty and Social Justice Are Being Sacrificed to the Gods of the Global Economy. Nova Iorque: Little Brown and Company, 1998 e Pat Buchanan, The Death of the West: How Dying Populations and Immigrant Invasions Imperil Our Country and Civilization. Nova Iorque: St. Martin's Press, 2002. Sobre o impacto do "buchananismo" na política americana, cf., Timothy Stanley, The Crusader: The Life and Tumultuous Times of Pat Buchanan. Nova Iorque: St. Martin's Press, 2012.

48 As palavras de Hillary Clinton, proferidas no dia 9 de setembro de 2016, foram as seguintes: "You know, to just be grossly generalistic, you could put half of Trump's supporters into what I call the basket of deplorables. Right? [Laughter/applause] The racist, sexist, homophobic, xenophobic, Islamaphobic - you name it. And unfortunately there are people like that. And he has lifted them up" o texto do discurso pode ser encontrado em: https: / time.com/4486502/ hillary-clinton-basket-of-deplorables-transcript. 
Enquanto os Democratas enfrentavam a tempestade perfeita, Donald Trump, adotando um discurso paradigmático do populismo moderno, denunciava as elites que tinham criado um país multicultural de "fronteiras abertas" e abandonado os valores fundacionais do Estado americano. Apresenta-se como porta-voz da "verdadeira" América, das suas tradições nacionais e do escasso poder - político, económico e cultural - que ainda permanecia nas mãos dos "deploráveis"49. Mais concretamente, responsabilizou Barack Obama pelas políticas de imigração que, direta ou indiretamente, desfizeram o tecido social do país. Ao abraçarem as especificidades das identidades étnica, de género e outras, as elites promoviam um assalto concertado às origens e tradições "anglo-saxónicas" do país, a única herança etnolinguística rejeitada em nome da "diversidade" ${ }^{50}$. Em consequência da adoção desta "identity politics", o Partido Democrata afastou-se da "realidade dos trabalhadores", permitindo que Trump construísse a sua narrativa do "país profundo" traído pelas elites cosmopolitas ${ }^{51}$.

Dado que, na perspetiva de Donald Trump, o Estado existe para promover o bem-estar dos cidadãos "nativos", e não para ser o "refúgio para as populações mundiais", a política de imigração futura teria de assentar em duas premissas ${ }^{52}$. Primeira, os recursos finitos do Estado seriam alocados de forma a assegurar a melhoria de vida dos cidadãos nacionais, particularmente os "working people" fustigados pela globalização. Segunda, e em resultado da primeira premissa, a política de imigração teria de abandonar os critérios da diversidade e da abertura das fronteiras. Com efeito, o Estado americano teria, rapidamente, de restabelecer o controlo sobre as suas fronteiras. Esta perspetiva sobre a imigração, os muros e a insegurança económica, logicamente conduzia à rejeição da política externa internacionalista do establishment washingtoniano.

Porque, para Donald Trump, os fins primordiais do Estado americano residem na maximização da segurança física e do bem-estar material dos cidadãos, a política

49 Sobre este caldo cultural, cf., J. D. Vance, Hillbilly Elegy: A Memoir of a Family and Culture in Crisis. Nova Iorque: HarperCollins, 2016.

50 Sobre esta questão, cf., por exemplo, Reihan Salam, "White Fright: Does Donald Trump represent the ascendancy of white nationalism on the American right?", Slate, 4 de setembro 2015, disponível em http: / / www.slate.com/articles/news_and_politics / politics / 2015/09/donald_ trump_and_white_nationalism_does_the_candidate_s_rise_represent_the.ht.

51 Ver, inter alia, Ashley Jardina, White Identity Politics. Cambridge: Cambridge University Press, 2019 e Eric Kaufmann, Whiteshift: Populism, Immigration and the Future of White Majorities. Londres: Allen Lane, 2018.

52 Donald Trump, no "discurso de Phoenix", delineou a sua política de imigração. Cf., Transcript of Donald Trump's Immigration Speech, The New York Times, 1 de setembro de 2016. Disponível em https://www.nytimes.com/2016/09/02/us/politics/transcript-trump-immigration-speech.html?_r=0 
externa deve pautar-se, exclusivamente, pelo interesse nacional ${ }^{53}$. Não obstante este ponto de vista, muito dificilmente se pode caracterizar a abordagem do presidente americano como uma viragem isolacionista. A bom rigor, o abandono do globalismo e o concomitante reforço da soberania dos Estados Unidos pretendido por Trump visa o oposto do isolacionismo, isto é, pretende reconfigurar relações de poder, as normas internacionais e as instituições multilaterais de forma a garantir a primazia dos interesses americanos. A rejeição da ordem liberal, do globalismo, não é sinónimo de um "regresso a casa" isolacionista, de um abandono da presença americana no mundo. Significa, simplesmente, que os Estados Unidos tencionam interagir com o mundo de acordo com novas regras. A distinção não é meramente semântica.

Ao mesmo tempo que Trump criticava o globalismo, os líderes do Brexit rejeitavam a permanência do Reino Unido na União Europeia, entendida como a expressão regional da globalização ${ }^{54}$. Durante a campanha que antecedeu o referendo de 23 junho de 2016, Nigel Farage, Boris Johnson, Michael Gove e outros rostos do Leave confrontaram os votantes com dois argumentos principais. Primeiro, a saída do Reino Unido da União Europeia tornara-se necessária para recuperar a soberania do país e a primazia do parlamento britânico, ou seja, a intenção expressa era "to take back control" das instituições e dos destinos nacionais. O segundo argumento, independentemente das ambiguidades e contradições, salientava que a imigração seria limitada para assegurar a sustentabilidade do welfare state e para distribuir os frutos do Estado social de forma mais restritiva, propósito entendido como outra dimensão do "taking back control" dos destinos nacionais. Nos anos que se seguiram à votação, e à medida que o Brexit provocava inúmeros impasses, os partidos populistas continentais abandonaram as suas tradicionais reivindicações quanto ao abandono do euro/União Europeia, passando a advogar a "mudança por dentro" das instituições europeias.

Após a aprovação do Brexit, a surpreendente vitória de Donald Trump fora recebida pelos populistas continentais como uma espécie de confirmação de que se encontravam do "lado certo" da História. Na realidade, Trump e os populistas europeus coincidem em vários assuntos, incluindo a necessidade de "renacionalizar" elites que alegadamente sacrificavam o interesse nacional aos compromissos e às alianças externas, particularmente a NATO e a União Europeia, as instituições mais representativas do globalismo na Europa. Ao encorajar os apoiantes do Brexit, e ao

53 Cf., Ian Hanchett, "Trump: Federal government's top three functions are security, healthcare, and education", Breitbart, 29 de março de 2016. Consultado em: http:/ / www.breitbart.com/ video/2016/03/29/ trump-federal-governments-top-three-functions-are-security-healthcare-and-education.

54 Ver o excelente trabalho de Kevin O'Rourke, A Short History of Brexit: From Brentry to Backstop. Londres: Pelican, 2019. 
proferir declarações claramente prejudiciais à coesão da Aliança Atlântica, o novo presidente americano sinalizava a sua intenção de rever os pressupostos da política externa americana relativamente à NATO e à integração europeia. Para os populistas, na altura ainda comprometidos com a saída dos seus respetivos países do euro/União Europeia, Trump não era nada menos do que um aliado objetivo capaz de enfraquecer as instituições representativas do globalismo no continente.

Por outro lado, o sucesso eleitoral de Trump trouxe à superfície as ambiguidades dos populistas relativamente aos Estados Unidos. Populistas europeus, tanto esquerdistas como direitistas, tendem a partilhar um conjunto semelhante de apreciações quanto aos Estados Unidos, desde a "arrogância imperial", à "imaturidade histórica", ao "materialismo crasso" e à "ingenuidade" das suas gentes. Lars Rensmann, num artigo publicado no início do século, observara que, nessa época, o "antiamericanismo está no topo da agenda dos partidos da extrema-direita pela Europa" ${ }^{55}$. Similarmente, Christina Schori Liang afirmava que, no pós-Guerra Fria, o antiamericanismo aumentara no seio da extrema-direita, que considerava os Estados Unidos como o maior adversário da Europa ${ }^{56}$. Dominando as instituições internacionais globalistas que limitam a soberania nacional, e porque a grande finança e as grandes empresas encontram-se sediadas nos Estados Unidos, os americanos eram vistos pelos populistas como os arquitetos e os principais defensores da ordem globalizada.

Porém, como demonstrou Simon Schama no seu ensaio "The Unloved American", as desconfianças europeias relativamente aos Estados Unidos remontam à fundação da república ${ }^{57}$. É evidente que, no campo direitista, o antiamericanismo esbateu-se durante as décadas de guerra fria pela simples razão de que o comunismo era o inimigo existencial da direita nacionalista. Na época, o antiamericanismo, era um monopólio virtual da esquerda radical europeia. Não admira, pois, que, por exemplo, a Front National (FN) francesa se assumisse como pró-americana antes do colapso do comunismo na Europa Central e na União Soviética. Posteriormente, durante a primeira guerra do Golfo Pérsico, a FN traçou um posicionamento mais crítico relativamente aos Estados Unidos. Similarmente, o Partido da Liberdade austríaco (FPÖ), ao longo de muitos anos liderado por Jörg Haider, foi solidário

55 Cf., Lars Rensmann, "The New Politics of Prejudice: Comparative Perspectives on Extreme Right Parties in European Democracies", German Politics \& Society, vol. 21, no. 4, 2003, p. 119.

56 Cf., Christina Schori Liang, "Europe for the Europeans: The Foreign and Security Policy of the Populist Radical Right", em Christina Schori Liang (ed.), Europe for the Europeans: The Foreign and Security Policy of the Populist Radical Right. Aldershot: Ashgate, 2007, pp. 1-32.

57 Cf., Simon Schama, "The Unloved American: Two centuries of alienating Europe", The New Yorker, 2 de março de 2003. Consultado em: https: / / www.newyorker.com/magazine / 2003/03/10/ the-unloved-american. 
com as posições de Washington até ao início da década de 2000, altura em que Haider se aproxima de Saddam Hussein. A vitória eleitoral de Trump e o seu discurso antiglobalismo atenuou, por enquanto, o antiamericanismo dos nacional-populistas europeus.

Atendendo a estes dados, também não deve surpreender a crescente coincidência de pontos de vista entre os líderes populistas europeus e Vladimir Putin, cujo objetivo estratégico principal passa pela abertura de brechas na coesão dos aliados transatlânticos. Na medida em que se insurgem contra a União Europeia, a NATO e a hegemonia dos Estados Unidos, os populistas europeus - tanto de esquerda como de direita - são aliados objetivos de Putin. É neste quadro que as declarações de Trump a caracterizar a Aliança Atlântica como "obsoleta" geraram desconfiança sobre o papel que o presidente vislumbrava para os Estados Unidos na região ${ }^{58}$. Mais recentemente, o populismo europeu tem vindo a convergir com Putin (e, em certa medida, com Trump) na leitura feita da sociedade americana. Na perspetiva do autocrata russo, os EUA abandonaram os valores tradicionais da cristandade, substituindo-os pelo individualismo e pelo materialismo corrosivos da civilização ocidental. A extensão dos direitos das minorias, incluindo a legalização de casamentos do mesmo sexo, indiciam sociedades "decadentes" que deixaram de ser verdadeiramente representativas do Ocidente. Confrontados com as mudanças de valores e comportamentos verificados na sociedade americana, os partidos de extrema-direita certamente olhavam cada vez mais para os Estados Unidos como o exemplo dos riscos inerentes às mudanças que combatem.

Alguns temas suscitados pelas campanhas de Donald Trump e do Brexit também seriam desenvolvidos por Jair Bolsonaro durante a contenda presidencial brasileira de 2018. Apesar de ter cumprido vários mandatos ao longo de três décadas como membro da Câmara dos Deputados do Congresso federal, Bolsonaro, tal como Trump e Farage, conseguiu preservar o estatuto de "outsider" da política brasileira, o traço distintivo da sua "marca" eleitoral ${ }^{59}$. Sistematicamente reprovadas pela comunicação social, as polémicas lançadas por Bolsonaro ao longo

58 Donald Trump, alguns meses depois, afirmou que a NATO não se encontrava "obsolete". Sobre a evolução da posição do presidente americano, cf., Peter Baker, "Trump's Previous View of NATO Is Now Obsolete", The New York Times, 13 de abril de 2017, disponível em: https: / / www. nytimes.com/2017/04/13/world/europe/nato-trump.html?_r=0.

59 Figura relativamente marginal da política brasileira, usualmente descrito como um excêntrico de extrema-direita, Bolsonaro celebrizou-se aquando do impeachment de Dilma, dedicando o seu voto à memória do coronel Carlos Alberto Brilhante Ustra, descrito por Bolsonaro como "o pavor de Dilma Rousseff". Cf., "Bolsonaro menciona chefe do Doi-CODI ao votar pelo impeachment", disponível em: https: / / oglobo.globo.com/brasil/bolsonaro-menciona-chefe-do-doi-codi-ao-votar-pelo-impeachment-2-19112343. 
dos anos reforçaram a perceção de que o "capitão" era o último reduto na defesa dos valores e instituições tradicionais ameaçadas pelo Partido dos Trabalhadores (PT). Pautou o seu discurso pela rejeição de "elites corruptas" manifestamente incapazes de garantir o desenvolvimento e a segurança de um país fustigado pela criminalidade e pelas gritantes desigualdades socioeconómicas. Este fracasso do establishment evidenciava-se a outro nível: ao abandonarem os valores da pátria e da família, as elites desfizeram as hierarquias assentes na autoridade e na tradição. Por conseguinte, na perspetiva do "bolsonarismo", generalizou-se o desrespeito pelas instituições nacionais, particularmente pelas forças armadas. Daí o apelo à restauração da "grandeza nacional" do Brasil.

Partindo deste entendimento do país e do desempenho das suas elites, o discurso de Bolsonaro invoca diversos temas comuns a outros populismos. Há, todavia, um elemento típico do populismo euro-americano que manifestamente se encontra ausente do discurso de Bolsonaro: a rejeição da dimensão económica da globalização. Se é verdade que Bolsonaro não defende o globalismo, é igualmente verdade que também não rejeita o neoliberalismo. Aliás, não deixa de ser notável constatar que Bolsonaro conquista o Palácio da Alvorada depois de apresentar um programa inequivocamente neoliberal, reivindicando a reforma da previdência nacional, a desburocratização e a retirada do Estado da economia através das privatizações. Ao mesmo tempo, a indicação de Paulo Guedes para a chefia do ministério da Economia sinalizava um inquestionável compromisso com a agenda neoliberal. À semelhança do peronismo de Carlos Menem, do Tea Party e do AKP de Erdoğan, Bolsonaro, casava o populismo com soluções neoliberais, assim demonstrando a compatibilidade do populismo com conteúdos ideológico-programáticos diversos ${ }^{60}$.

Uma vez que o universo populista usualmente enfatiza a contestação à dimensão económica da globalização, a centralidade da crítica feita por Jair Bolsonaro à dimensão cultural do globalismo parece anómala. No seu blog pessoal, pouco tempo antes de ter assumido o cargo de ministro das Relações Externas, Ernesto Araújo reprovara a dimensão cultural da globalização nos seguintes termos: "Quero ajudar o Brasil e o mundo a se libertarem da ideologia globalista. Globalismo é a globalização econômica que passou a ser pilotada pelo marxismo cultural. Essencialmente

60 Cf., inter alia, S. E. Aytaç e Z. Öniş, "Varieties of Populism in a Changing Global Context: The Divergent Paths of Erdoğan and Kirchnerismo", Comparative Politics, vol. 47, no. 1, pp. 41-59; U. Bozkurt, "Neoliberalism with a human face: Making sense of the Justice and Development Party's neoliberal populism in Turkey", Science \& Society, vol. 77, no. 3, 2013, pp. 372-396; E. Özbudun, "From Political Islam to Conservative Democracy: The Case of the Justice and Development Party in Turkey", South European Society \& Politics, vol. 11, nos. 3-4, 2006, pp. 543-557 e K. Weyland, "Neoliberal Populism in Latin America and Eastern Europe", Comparative Politics, vol. 31, no. 4, 1999, pp. 379-401. 
é um sistema anti-humano e anticristão. A fé em Cristo significa lutar contra o globalismo, cujo objetivo último é romper a conexão entre Deus e o homem, tornado o homem escravo e Deus irrelevante. O projeto metapolítico significa, essencialmente, abrir-se para a presença de Deus na política e na história"61. Dito de outra forma, a globalização económica é entendida por Araújo como uma consequência do domínio ideológico do "marxismo cultural" propagado através da hegemonia exercida pelo PT nas universalidades, nas artes e na política. Todavia, dado que a intervenção estatal na economia e o protecionismo estavam associados à governação de Lula e Dilma, o neoliberalismo passou a ser entendido como um instrumento para quebrar a hegemonia da esquerda "petista".

Um segundo aspeto que diferencia o populismo de Bolsonaro prende-se com a inexistência do discurso antiamericano historicamente conotado com os populismos latino-americanos. Bolsonaro abertamente reclama uma maior aproximação aos Estados Unidos, admitindo a sua disponibilidade para conceder ao país bases militares em solo brasileiro. Atendendo à existência de uma corrente direitista hostil a Washington entrincheirada nas forças armadas, a mera possibilidade de conceder bases a Washington configurava uma viragem significativa na política externa do Itamaraty. Justificando este tilt relativamente aos Estados Unidos, Bolsonaro apontou a necessidade de reduzir a dependência do Brasil em relação à China. Em pleno contraste com o internacionalismo terceiro-mundista do PT, o nacionalismo de Bolsonaro constitui uma repudiação global do legado do partido. É justamente neste ponto que reside a coerência política e discursiva do presidente brasileiro, assim desfazendo a aparente anomalia do seu populismo.

\section{Conclusão}

Ao anunciar a intenção de restituir a grandeza dos Estados Unidos, Donald Trump propôs-se resgatar Washington das "elites corruptas" que, ao longo de décadas, transformaram a cidade num "pântano" de incompetência responsável pelo declínio do país ${ }^{62}$. Por outras palavras, e à semelhança de outros populistas, reproduziu a narrativa quanto à decadência nacional provocada por elites corruptas e a necessidade de eleger um líder forte capaz de consumar a rutura com o establishment e efetuar a "regeneração" nacional. Recorde-se que um dos pilares estruturantes da política externa de Trump é a rejeição dos acordos comerciais mais emblemáticos

61 As palavras constam do perfil do autor no seu blog pessoal, consultado em https: / / www.metapoliticabrasil.com/about.

62 Ver o livro "programático" de Trump, Donald J. Trump, Great Again: How to Fix our Crippled America. Nova Iorque: Threshold Editions, 2015. 
das últimas décadas que efetivamente consolidaram a globalização ${ }^{63}$. Se é verdade que o presidente mantém que não se opõe ao comércio livre, também é verdade que se declara desfavorável ao "comércio injusto" instituído por tratados como o NAFTA e consubstanciado no relacionamento comercial com a China. Voltar à "América grande" obriga, pois, a uma revisão profunda das regras e das instituições que têm moldado o globalismo.

Também os partidos e movimentos populistas europeus conduziram, ao longo das últimas décadas, a uma luta sem quartel contra as elites "europeístas". Entendida como a expressão regional da ordem globalista, Bruxelas passou a ser identificada como a fonte principal dos problemas nacionais. Na medida em que as dificuldades do processo de integração se acentuaram no contexto da crise internacional iniciada em 2008, a mensagem de "resistência cultural" disseminada pelos partidos populistas encontrou eco junto dos eleitores. Face aos anseios provocados pela insegurança económica e cultural que tem alastrado pelos países ocidentais, os populistas advogam, como alternativa política, o reforço do Estado como instrumento para retomar o "controlo" dos destinos das comunidades nacionais. Com efeito, o populismo europeu configura uma tentativa de utilizar o estado nacional, e a mobilização nacionalista, para responder às inseguranças económicas e culturais provocadas pela globalização.

Convém reconhecer que o populismo passou a ser um elemento permanente, estruturante da paisagem política europeia contemporânea. Dito de outra forma, num horizonte previsível, o populismo veio para ficar. Acrescenta-se que o destino destes partidos é indissociável da vaga mundial populista que tem levado inúmeros homens fortes ao poder nos quatro cantos do mundo. A breve prazo, dois fatores são especialmente determinantes para os populistas europeus. Primeiro, e mais importante, a eventual reeleição de Donald Trump em 2020. Caso volte a conquistar a Casa Branca, Trump continuará a desmantelar a ordem globalista e, assim, provocará um "efeito contágio" que seguramente reforçará os populistas continentais. Segundo, a condução do processo Brexit, e os seus resultados socioeconómicos, terá uma influência decisiva nas estratégias populistas e junto da opinião pública que teme as consequências inerentes à desintegração da União Europeia. Trata-se de uma espécie de "test case" cujas repercussões serão sentidas muito para além das fronteiras do Reino Unido. De qualquer forma, convém não ignorar que os populistas são os "canários da mina" das democracias pluralistas que alertam para anseios e disfuncionalidades potencialmente devastadoras para as liberdades.

63 Donald Trump chegou a caracterizar o NAFTA como o "pior" acordo comercial jamais celebrado. Cf., David P. Fidler, "President Trump, Trade Policy, and American Grand Strategy: From Common Advantage to Collective Carnage", Asian Journal of WTO \& International Health Law and Policy, vol. 12, no. 1, março de 2017, pp. 1-31. Disponível em https://ssrn.com/abstract $=2948199$. 